\title{
ASSESSMENT OF TRACE METALS CONTAMINATION OF SOILS AROUND SOME AUTOMOBILE MECHANIC WORKSHOPS IN OYO SOUTH-WESTERN NIGERIA
}

ROLAND A. ISIBOR

(Received 11 March 2016; Revision Accepted 15 April 2016)

\begin{abstract}
This study was carried out to determine the level of soil contamination by metals around some automobile mechanic workshops in Oyo town in order to assess their possible adverse health implications on man and his environment. Concentrations of metals above certain levels have been shown to impair man's health. Automobile mechanic workshops are sources of metals discharge into the environment and most of these workshops in Oyo are sited within residential areas. 12 samples of top soils were therefore collected from some automobile mechanic workshops within Oyo town and analyzed for Lead (Pb), Manganese (Mn), Zinc ( $\mathrm{Zn})$, Chromium (Cr), Vanadium (V), Copper (Cu), Strontium ( $\mathrm{Sr}$ ), Cobalt (Co), Nickel (Ni) and Cadmium (Cd) using the Inductively Coupled Plasma Mass Spectrometry (ICP-MS) technique. The indices of contamination including Geo-accumulation index, Contamination Factor, and Degree of Contamination were used to determine the pollution status of the soils. $\mathrm{Pb}$ and $\mathrm{Zn}$ were the main metals of pollutant status with $\mathrm{Pb}$ having very high Contamination Factor, and the soils in general showing very high degree of contamination. This high level of $\mathrm{Pb}$ and $\mathrm{Zn}$ in the environment is significant with possible health risk to man and his environment.
\end{abstract}

KEYWORDS: Automobile mechanic workshops, Contamination Factor, Degree of Contamination, Geo-accumulation Index, Oyo town, Soils.

\section{INTRODUCTION}

Human civilization and development has led to rapid industrialization and urbanization of our societies. Resulting from rapid industrialization, urbanization (Jiang et al.2013) and the attendant economic activities such as mining (Navarro et al, 2008) agriculture (Vaalgamoa and Conley 2008, Syed et al. 2012), industries and transportation (Jaradat et al. 2005; David and Sunday, 2012), is the generation of huge waste, leading to the contamination of environmental resources. The various wastes generated release trace metals into the environment. Although trace metals are essential for healthy biological function, they can become toxic to living things at concentrations above that required for normal biological activities (Fraga, 2005).

It has been noted that toxicity of metals can cause enzyme inactivation, acute mental skipping, and severe damage to gastrointestinal tract, kidney, liver and the central nervous system (Landrigon,1994). Also, heavy metal toxicity has an inhibitory effect on plant functions (Johansson et al., 1998).

Consequently, metal pollution because of its adverse effect on man is of global concern and effort is being made at regulating their discharge into the environment. One direct effect of urbanization is the contamination of urban soils, which subsequently serves adversely as a transmitter of many pollutants to surface waters, groundwater, atmosphere and food (Hani and Kariminejad, 2010). Once in the food chain and ecosystem, trace metals become a potential risk to man
(Tamane, 2008; Cai et al, 2011). Soils around automobile mechanic workshops are particularly susceptible to metal contamination (Ololade, 2014; Olanrewaju et al, 2015).

There has been a gradual increase in the number of automobile mechanic workshops in many cities of Nigeria as a result of urban development and increase in population. Waste from these automobile mechanic workshops are disposed and dumped indiscriminately into the environment often leading to soil contamination (Aelion, Davis, McDermott and Lawson, 2009). Generally, studies have shown that soils around automobile mechanic workshops are more polluted than the surrounding soils in metals like $\mathrm{Pb}, \mathrm{Ni}, \mathrm{Cd}, \mathrm{Cu}, \mathrm{Cr}$, $\mathrm{Mn}$ and $\mathrm{Zn}$ which are often contained as additives in some lubricants and gasoline (Ololade, 2014).

Currently Oyo town is experiencing an increase in population and economic activities as a result of influx of workers and intakes into recently established tertiary institutions and industries. This increase in population has led to an increase in the frequency of automobile mechanic activities and number of automobile mechanic workshops. The implication of this is that the environment will experience an increase in automobile/automobile mechanic workshop related metal pollution. Therefore it is important to determine the concentration and degree of metal contamination in soils around these mechanic workshops in order to estimate possible health risks on the inhabitants of Oyo town. This study is therefore aimed at the determination of concentrations and degree of trace metals contamination in soils around some automobile 
workshops in Oyo town using Geoaccumulation index and Degree of Contamination of the trace metals in the soils.

\subsection{MATERIALS AND METHODS}

2.1 Study Area and Sampling

This investigation was carried out within twelve automobile mechanic workshops in Oyo town, south- western Nigeria. Oyo town is about $50 \mathrm{~km}$ north of Ibadan and is located within longitude $3^{05} 5^{\prime} \mathrm{E}$ and $3^{05} 7^{\prime}$ $\mathrm{E}$ and latitude $7050^{\prime} \mathrm{N}$ and $7052^{\prime} \mathrm{N}$. Oyo town lies mostly on lowlands which are punctuated by rocky outcrops and series of hills. The study area has undulating topography with moderate elevations ranging from $53 \mathrm{~m}$ to $317 \mathrm{~m}$ above sea level (Fig. 1).

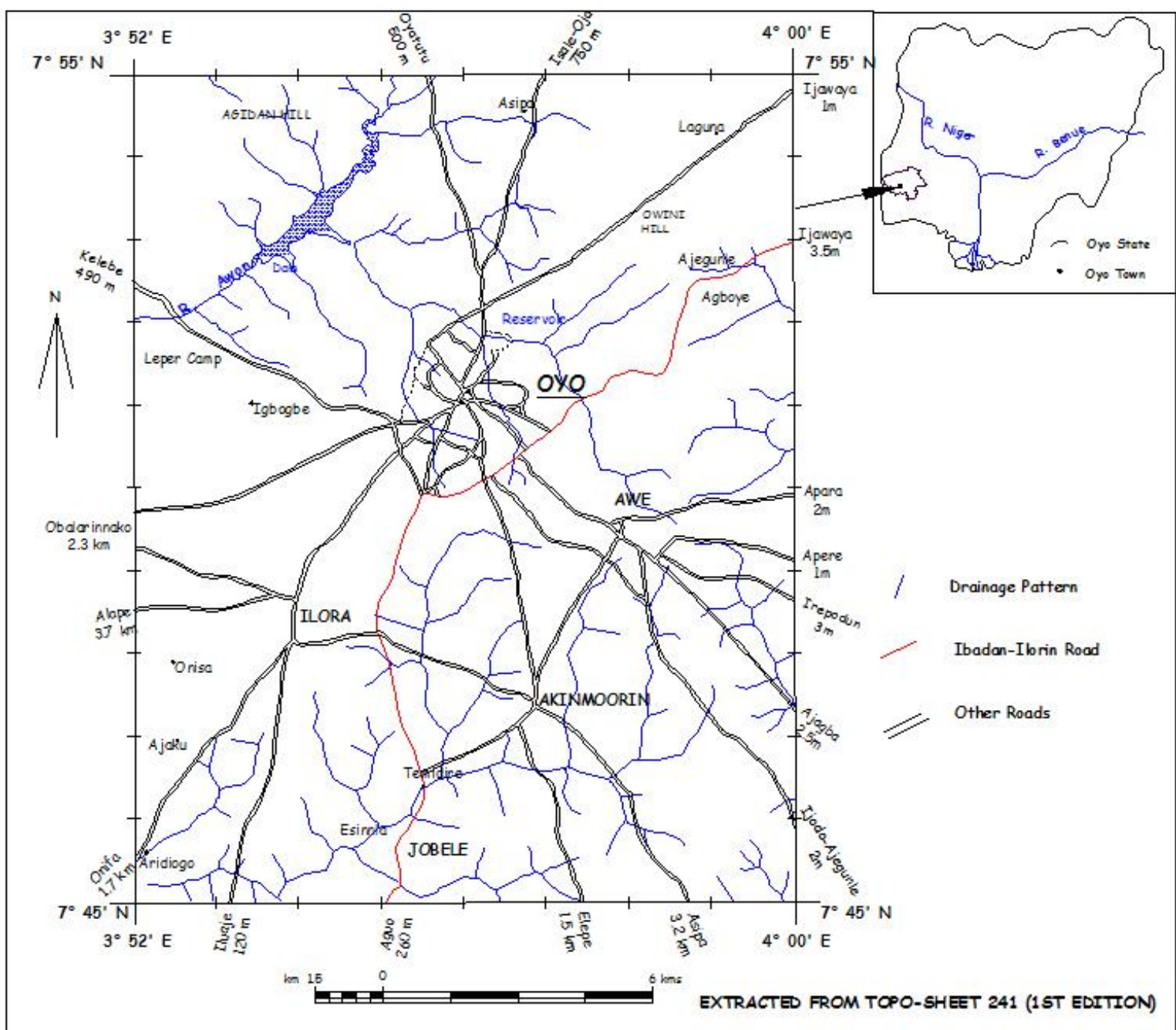

Fig. 1: Map of Oyo town (extracted from topo-sheet $2411^{\text {st }}$ edition)

Oyo town lies within the tropical rain forest belt which exhibits the typical climate of averagely high temperatures, high relative humidity and generally two rainfall maxima regime during the rainfall period of March to October. The mean temperature are highest at the end of the harmattan (averaging $28^{\circ} \mathrm{C}$ ) that is from the middle of January to the onset of the rains in the middle of March, even during the rainfall months temperature range between $25^{\circ} \mathrm{C}$ and $35^{\circ} \mathrm{C}$ almost throughout the year (Filani and Akintola, 1982). Rainfall figures vary from average of $120 \mathrm{~mm}$ at the onset of heavy rains to an average between $800 \mathrm{~mm}$ and $1500 \mathrm{~mm}$. Oyo town lies within the Precambrian Basement Complex of South-western Nigeria, which is part of the Proterozoic mobile belt located between the West-African and Congo Cratons (Jones and Hockey, 1964; Rahaman, 1976; Dada, 2006). Rock types in the study area include migmatite, quartzite, biotite schist, biotite gneiss, granite, granite gneiss, and biotite-garnet schist (NGSA, 2008) (Fig.

2). 


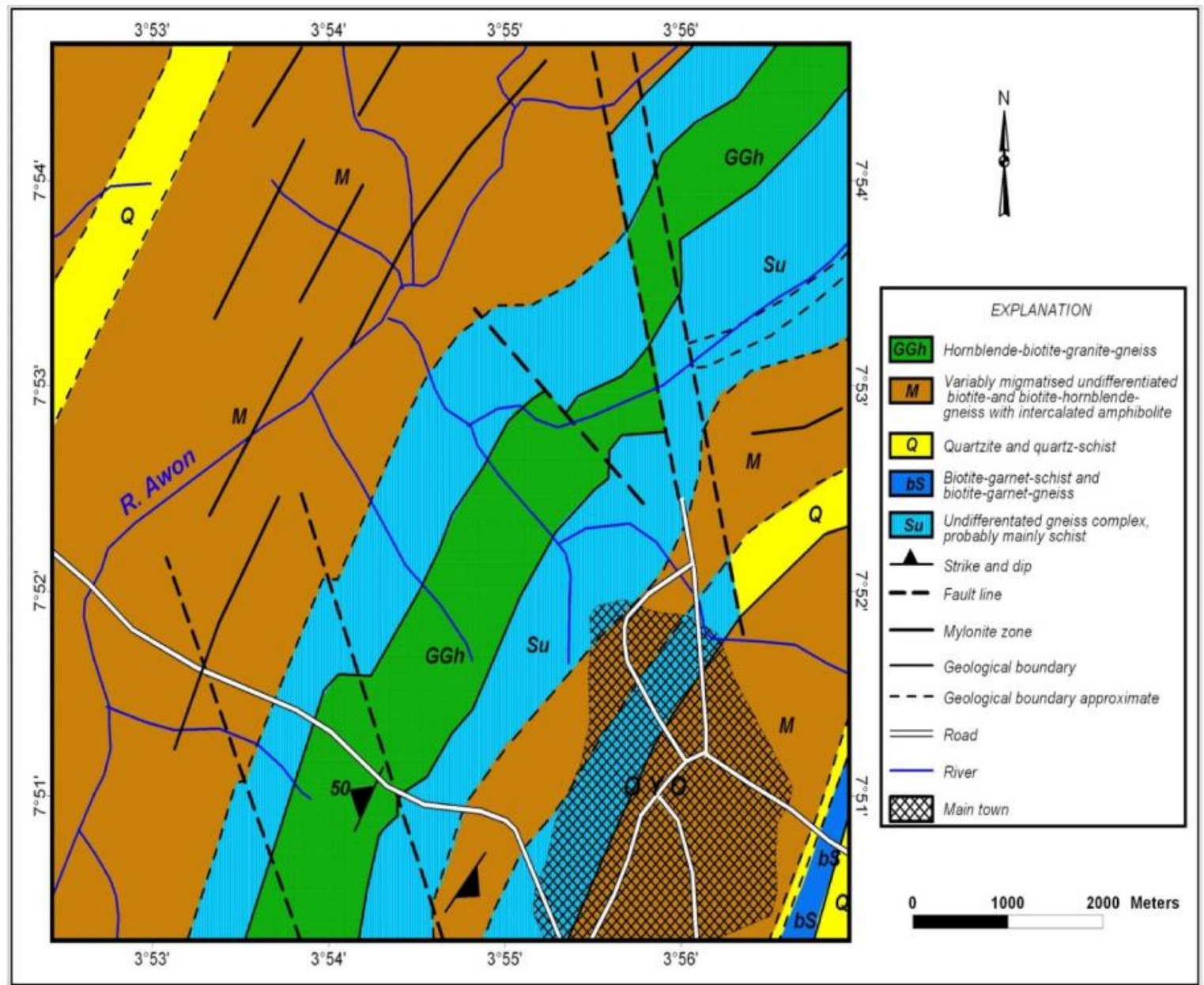

Fig. 2: Geological Map of Oyo town and its environs(published by Nigeria Geological Survey Agency, 2008)

Samples for this study were collected from some selected automobile mechanic workshops in Oyo town (Fig. 3, Table 1). The workshops were selected to represent various commercial centers of Oyo town where vehicular activities are relatively high. Topsoil samples were taken from 12 different locations at a depth of 0 to $15 \mathrm{~cm}$ with plastic hand trowels into polyethylene bags and marked to indicate the location of collection, the GPS readings were also noted. 


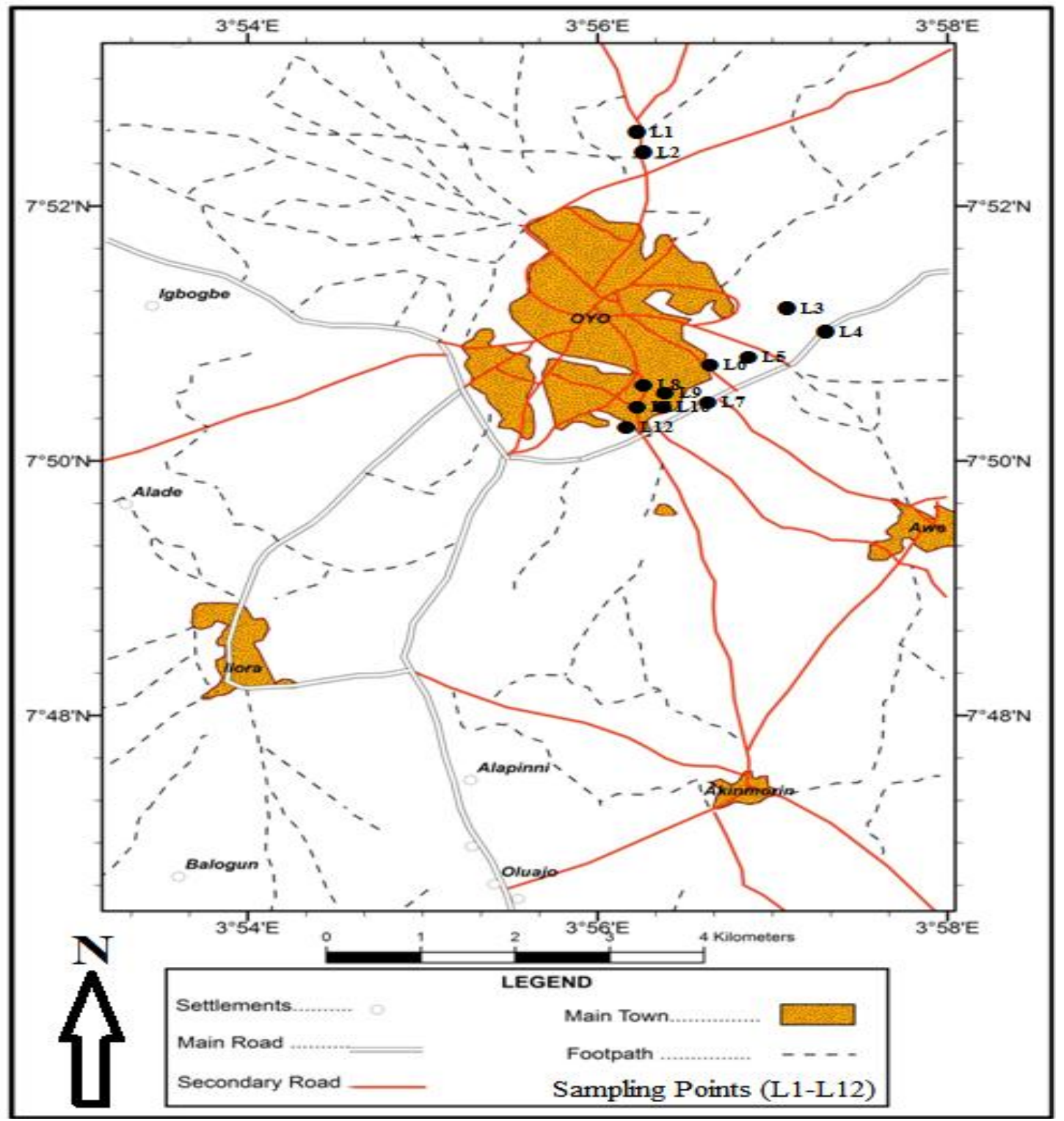

Fig. 3: Points of sample collection in Oyo

Table 1: Sampling Locations

\begin{tabular}{|l|l|l|l|}
\hline S/N & Sampling location & Latitude & Longitude \\
\hline L1 & Alasila junction, Sabo & $\mathrm{N} 07^{\circ} 52^{\prime} 35.2^{\prime \prime}$ & $\mathrm{E} 003^{\circ} 56^{\prime} 08.2^{\prime \prime}$ \\
\hline L2 & Isale Oyo area, Sabo & $\mathrm{N} 07^{\circ} 52^{\prime} 26.8^{\prime \prime}$ & $\mathrm{E} 003^{\circ} 56^{\prime} 10.6^{\prime \prime}$ \\
\hline L3 & Adewale street junction,Ajegunle & $\mathrm{N} 07^{\circ} 51^{\prime} 08.4^{\prime \prime}$ & $\mathrm{E} 003^{\circ} 57^{\prime} 03.5^{\prime \prime}$ \\
\hline L4 & Beside Bizinilahi filling station,Ajegunle & $\mathrm{N} 07^{\circ} 51^{\prime} 00.1^{\prime \prime}$ & $\mathrm{E} 003^{\circ} 57^{\prime} 16.1^{\prime \prime}$ \\
\hline L5 & $\begin{array}{l}\text { Akunlemu garage extension beside School of } \\
\text { Surveying }\end{array}$ & $\mathrm{N} 07^{\circ} 50^{\prime} 34.5^{\prime \prime}$ & $\mathrm{E} 003^{\circ} 56^{\prime} 48.8^{\prime \prime}$ \\
\hline L6 & Inside Akunlemu garage, along Ogbomoso-Oyo road & $\mathrm{N} 07^{\circ} 50^{\prime} 34.1^{\prime \prime}$ & $\mathrm{E} 003^{\circ} 56^{\prime} 35.4^{\prime \prime}$ \\
\hline L7 & Beside FIRS building, Opposite Awe junction & $\mathrm{N} 07^{\circ} 50^{\prime} 25.7^{\prime \prime}$ & $\mathrm{E} 003^{\circ} 56^{\prime} 36.4^{\prime \prime}$ \\
\hline L8 & Front of Gbadegesin's palace, Oke-Apo & $\mathrm{N} 07^{\circ} 50^{\prime} 30.9^{\prime \prime}$ & $\mathrm{E} 003^{\circ} 56^{\prime} 11.9^{\prime \prime}$ \\
\hline L9 & Behind Anglican Secondary School, Ajagba & $\mathrm{N} 07^{\circ} 50^{\prime} 28.5^{\prime \prime}$ & $\mathrm{E} 003^{\circ} 56^{\prime} 19.2^{\prime \prime}$ \\
\hline L10 & Behind Methodist Maternity Centre, Ajagba & $\mathrm{N} 07^{\circ} 50^{\prime} 25.6^{\prime \prime}$ & $\mathrm{E} 003^{\circ} 56^{\prime} 18.4^{\prime \prime}$ \\
\hline L11 & Behind Speaker OYHA's house, Ajagba & $\mathrm{N} 07^{\circ} 50^{\prime} 24.4^{\prime \prime}$ & $\mathrm{E} 003^{\circ} 56^{\prime} 14.2^{\prime \prime}$ \\
\hline L12 & Durbar road, Tengba & $\mathrm{N} 07^{\circ} 50^{\prime} 14.4^{\prime \prime}$ & $\mathrm{E} 003^{\circ} 56^{\prime} 10.0^{\prime \prime}$ \\
\hline
\end{tabular}

The soil samples were air dried in the laboratory, and sieved through a $<0.075 \mathrm{~mm}$ polyethylene sieve to remove stones, roots, coarse materials and other debris. To prevent contamination, after a sample from a location was sieved, the sieve and the pan were thoroughly brushed out and cleaned with 
acetone before another sample was put in for sieving and this was done all through the sample preparation. Samples that appeared too clustered were disaggregated in a porcelain mortar with a pestle. The shaking was done by a mechanical sieve shaker and then the sieved portion $(<0.075 \mathrm{~mm})$ was collected and a fraction packaged into air-tight polythene bag which was later sent to ACME laboratories, Vancouver, Canada for further geochemical analysis.

Aqua Regia Digestion Method was employed to digest the soil samples. $0.5 \mathrm{~g}$ of each sample was digested using aqua regia $\left(0.5 \mathrm{ml} \quad \mathrm{H}_{2} \mathrm{O}, \quad 0.6 \mathrm{ml}\right.$ concentrated $\mathrm{HNO}_{3}$ and $1.8 \mathrm{ml}$ concentrated $\mathrm{HCl}$ ) for 2 hours at $95^{\circ} \mathrm{C}$. The solutions were then cooled and diluted to $10 \mathrm{ml}$ with deionized water in readiness for trace element determination of the samples.

\subsection{Sample Analysis}

The samples were analyzed using the Inductively Coupled Plasma Mass Spectrometry (ICP-MS). This was achieved by ionizing the sample with inductively coupled plasma and then using the spectrometer to separate and quantify the ions. In inductively coupled plasma, plasma is energized by inductively heating the gas with an electrical coil. The plasmas used in spectrochemical analysis are essentially electrically neutral, with each positive charge on an ion balanced by a free electron. The concentrations of elements in each sample was determined through calibration with certified reference materials.

\subsection{STATISTICAL ANALYSIS OF THE SOIL SAMPLES}

\subsection{Descriptive Statistics}

The mean, range and standard deviation were calculated for the samples.

\subsection{Correlation Factor}

The degree of correlation between two variables is usually calculated by applying a coefficient of correlation on data containing the two variables. A perfect positive correlation between the two variables results in a coefficient of +1 , a perfect negative correlation between two variables results in a coefficient of -1 , and a total absence of correlation in a coefficient of 0 . Intermediate values between $+1,0$ and -1 are interpreted by degree of correlation. Thus, 0.98 indicates high positive correlation, -0.95 indicates high negative correlation and 0.09 indicates low positive correlation.

\subsection{CONTAMINATION INDICES}

\subsection{Geoaccumulation Index}

The Index of geoaccumulation (Igeo) was used for the assessment of soil contamination. It is computed using an equation developed by Muller (1969) and it is expressed mathematically as:

$\operatorname{Igeo}=\log _{2} \mathrm{Cn} / 1.5 \mathrm{Bn}$

Where:

$\mathrm{Cn}$ is the measured concentration of the element in the soil sample fraction

$\mathrm{Bn}$ is the geochemical background value (the average crustal abundance value for each metal was used for this study).

The constant 1.5 allows for analysis of natural fluctuations in the content of a given substance in the environment and very small anthropogenic influences.

The soil quality can be subsequently referred to using the following values of Igeo as shown in Table 2

Table 2: Classes of Geoaccumulation Index (Igeo) after Muller, 1969.

\begin{tabular}{lll}
\hline Class & Igeo Value & Soil Quality \\
\hline 0 & Igeo $\leq 0$ & Practically Uncontaminated \\
1 & $0<$ lgeo $\leq 1$ & Uncontaminated to Moderately Contaminated \\
2 & $1<$ lgeo $\leq 2$ & Moderately Contaminated \\
3 & $2<$ lgeo $\leq 3$ & Moderately to Heavily Contaminated \\
4 & $3<$ lgeo $\leq 4$ & Heavily Contaminated \\
5 & $4<$ lgeo $\leq 5$ & Heavy to Extremely Contaminated \\
6 & Igeo>5 & Extremely Contaminated \\
\hline
\end{tabular}

\subsection{Contamination Factor $\left(\mathrm{C}_{\mathrm{f}}\right)$ and Degree of Contamination $\left(\mathbf{C}_{\text {deg }}\right)$}

Soil contamination could also be assessed using the parameters: Contamination Factor and Degree of Contamination (Loska et al., 2004). In the version suggested by Hakanson (1980), soil contamination was assessed by comparing the observed concentration with pre-industrialized levels (average shale concentration).

$C_{f}^{i}=C_{0-i}^{i} / C_{n}^{i}$
Where:

$\mathbf{C}_{0-i}^{i}=$ mean concentration of metals from at least 5 sampling sites.

$\mathbf{C}_{n}{ }_{n}=$ pre - industrial concentration (for this work: the average crustal value was used) of the individual metal

Contamination factor is a single element index (Table 3). The sum of the Contamination Factor for all studied metals yield the contamination degree $\mathrm{C}(\mathrm{deg})$ of the entire studied area and is represented by four classes

(Table 
Table 3: Categories of Contamination factor

\section{Soil Category}

$$
\begin{aligned}
& C_{f<1}^{i} \\
& 1 \leq C_{f<3}^{i}<3 \\
& 3 \leq C_{f}^{i}<6 \\
& \leq C_{f}^{i}
\end{aligned}
$$

low contamination factor

moderate contamination factor

Considerable contamination factor

Very high contamination factor

Table 4: Categories of Contamination degree

\begin{tabular}{ll}
\hline Class of Contamination degree & Soil Category \\
\hline$C_{\text {deg }<} 8$ & low degree of contamination \\
$8 \leq C_{\text {deg }} 16$ & moderate degree of contamination \\
$16 \leq C_{\text {deg }} 32$ & Considerable degree of contamination \\
$32 \leq C_{\text {deg }}$ & Very high degree of contamination
\end{tabular}

\subsection{RESULTS AND DISCUSSIONS}

Results obtained from the geochemical analysis for the soil samples(Table 5)were subjected to various statistical analyses such as descriptive statistics, correlation and factor analysis. Geoaccumulation index, contamination factor and degree of contamination were also applied in determining the level of contamination of the soils.

Table 5: Result of the Geochemical Analysis

\begin{tabular}{|l|l|l|l|l|l|l|l|l|l|l|}
\hline & $\begin{array}{l}\mathrm{Cu} \\
(\mathrm{ppm})\end{array}$ & $\begin{array}{l}\mathrm{Pb} \\
(\mathrm{ppm})\end{array}$ & $\begin{array}{l}\mathrm{Zn} \\
(\mathrm{ppm})\end{array}$ & $\begin{array}{l}\mathrm{Ni} \\
(\mathrm{ppm})\end{array}$ & $\begin{array}{l}\text { Co } \\
(\mathrm{ppm})\end{array}$ & $\begin{array}{l}\text { Mn } \\
(\mathrm{ppm})\end{array}$ & $\begin{array}{l}\mathrm{Cd} \\
(\mathrm{ppm})\end{array}$ & $\begin{array}{l}\text { V } \\
(\mathrm{ppm})\end{array}$ & $\begin{array}{l}\mathrm{Cr} \\
(\mathrm{ppm})\end{array}$ & $\begin{array}{l}\text { Sr } \\
(\mathrm{ppm})\end{array}$ \\
\hline L 1 & 78 & 345 & 255 & 15 & 33 & 946 & 0.4 & 83 & 82 & 26 \\
\hline L 2 & 152 & 203 & 383 & 22 & 29 & 1453 & 0.5 & 56 & 47 & 89 \\
\hline L 3 & 34 & 25 & 74 & 15 & 34 & 1636 & 0.4 & 66 & 66 & 12 \\
\hline L 4 & 44 & 99 & 118 & 15 & 43 & 1620 & 0.4 & 117 & 75 & 32 \\
\hline L 5 & 95 & 123 & 374 & 132 & 66 & 1193 & 0.4 & 125 & 902 & 9 \\
\hline L 6 & 13 & 14 & 45 & 6 & 10 & 584 & 0.4 & 24 & 25 & 14 \\
\hline L 7 & 135 & 522 & 219 & 21 & 46 & 1831 & 0.4 & 173 & 140 & 17 \\
\hline L 8 & 169 & 10000 & 608 & 16 & 14 & 657 & 0.9 & 59 & 50 & 27 \\
\hline L 9 & 38 & 86 & 113 & 14 & 23 & 981 & 0.4 & 66 & 45 & 27 \\
\hline L 10 & 46 & 50 & 191 & 21 & 23 & 1135 & 0.4 & 62 & 53 & 49 \\
\hline L 11 & 142 & 307 & 555 & 27 & 27 & 1123 & 0.8 & 110 & 93 & 53 \\
\hline L 12 & 90 & 3028 & 745 & 19 & 17 & 729 & 0.9 & 100 & 67 & 66 \\
\hline
\end{tabular}

3.1. DESCRIPTIVE STATISTICS

\subsection{Geochemical Results}

The statistical summary of the elemental concentrations in the soil samples were presented in the Appendix.

The minimum value for $\mathrm{Cu}$ is $13.00 \mathrm{ppm}$ while the maximum value is $169.00 p p m$ with a mean value of 86.33ppm and standard deviation of 52.78ppm. $\mathrm{Pb}$ ranged from $14.00 \mathrm{ppm}$ to $10000.00 \mathrm{ppm}$ with a mean and standard deviation of 1233.50ppm and 2883.70ppm respectively. $\mathrm{Zn}$ has a mean and standard deviation of $306.67 \mathrm{ppm}$ and $228.51 \mathrm{ppm}$ respectively; it also ranges from 45.00ppm to 745.00ppm.

The minimum value for $\mathrm{Ni}$ is $6.00 \mathrm{ppm}$, while the maximum value is $132.00 \mathrm{ppm}$ with a mean of $26.92 \mathrm{ppm}$ and standard deviation of $33.51 \mathrm{ppm}$. Co ranged from 10.00ppm to $66.00 \mathrm{ppm}$ with a mean value and standard deviation value of $30.42 \mathrm{ppm}$ and $15.60 \mathrm{ppm}$ respectively.
Mn has a mean value of $1157.33 p p m$ and a standard deviation value of 407.39ppm, and ranged from 584.00ppm to $1831.00 p p m$.

The minimum value for $\mathrm{Cd}$ is $0.40 \mathrm{ppm}$, while the maximum value is $0.90 \mathrm{ppm}$. It has a mean value of $0.53 \mathrm{ppm}$ and standard deviation value of $0.21 \mathrm{ppm}$. Cr ranged from 25.00ppm to 902.00ppm with a mean value and standard deviation value of 137.08ppm and 242.66ppm respectively. Sr has a minimum value of $9.00 \mathrm{ppm}$ and maximum value of $89.00 \mathrm{ppm}$, a mean value of $35.08 p p m$ and standard deviation value of 24.47ppm. $V$ ranged from 24.00ppm to 173.00ppm, with a mean value of $86.75 \mathrm{ppm}$ and standard deviation value of $40.08 p p m$.

\subsection{Correlation Matrix}

The inter-elemental relationship was determined by measurement of their correlation coefficients (Table 6). 
Table 6: Correlation Matrix for metals in the soils

\begin{tabular}{|l|l|l|l|l|l|l|l|l|l|l|}
\hline & $\mathrm{Cu}$ & $\mathrm{Pb}$ & $\mathrm{Zn}$ & $\mathrm{Ni}$ & $\mathrm{Co}$ & $\mathrm{Mn}$ & $\mathrm{Cd}$ & $\mathrm{Cr}$ & $\mathrm{Sr}$ & $\mathrm{V}$ \\
\hline $\mathrm{Cu}$ & 1.000 & & & & & & & & & \\
$\mathrm{~Pb}$ & .525 & 1.000 & & & & & & & & \\
$\mathrm{Zn}$ & .720 & .597 & 1.000 & & & & & & & \\
$\mathrm{Ni}$ & .154 & -.124 & .175 & 1.000 & & & & & & \\
$\mathrm{Co}$ & .087 & -.389 & -.165 & .745 & 1.000 & & & & & \\
$\mathrm{Mn}$ & .069 & -.459 & -.373 & .086 & .652 & 1.000 & & & & \\
$\mathrm{Cd}$ & .592 & .724 & .906 & -.128 & -.457 & -.478 & 1.000 & & & \\
$\mathrm{Cr}$ & .098 & -.138 & .106 & .990 & .776 & .100 & -.188 & 1.000 & & \\
$\mathrm{Sr}$ & .399 & .016 & .511 & -.241 & -.330 & -.040 & .425 & -.350 & 1.000 & \\
$\mathrm{~V}$ & .344 & -.149 & .184 & .374 & .707 & .572 & -.011 & .407 & -.148 & 1.000 \\
\hline
\end{tabular}

The correlation coefficients vary widely from a minimum value of -0.011 between $\mathrm{Cd}$ and $\mathrm{V}$ to $\mathrm{a}$ maximum value of 0.990 between $\mathrm{Ni}$ and $\mathrm{Cr}$. Cu showed a high positive correlation with $\mathrm{Pb}, \mathrm{Zn}$ and $\mathrm{Cd}$, and a low positive correlation with $\mathrm{Ni}, \mathrm{Co}, \mathrm{Mn}, \mathrm{Cr}, \mathrm{Sr}$ and $\mathrm{V}$. $\mathrm{Pb}$ showed a high positive correlation with $\mathrm{Cu}, \mathrm{Zn}$ and $\mathrm{Cd}$, negative correlation with $\mathrm{Ni}, \mathrm{Co}, \mathrm{Mn}, \mathrm{Cr}$ and $\mathrm{V}$, and a low positive correlation with Sr.

$\mathrm{Zn}$ showed a high positive correlation with $\mathrm{Cu}$, $\mathrm{Pb}, \mathrm{Cd}$ and $\mathrm{Sr}$, a negative correlation with $\mathrm{Co}$ and $\mathrm{Mn}$ and a low positive correlation with $\mathrm{Ni}, \mathrm{Cr}$ and $\mathrm{V}$. $\mathrm{Ni}$ showed a high positive correlation with $\mathrm{Co}$ and $\mathrm{Cr}$, a low negative correlation with $\mathrm{Pb}, \mathrm{Cd}$ and $\mathrm{Sr}$ and a low positive correlation with $\mathrm{Cu}, \mathrm{Zn}, \mathrm{Mn}$ and V.

Co showed a high positive correlation with $\mathrm{Ni}$, $\mathrm{Mn}, \mathrm{V}$ and $\mathrm{Cr}$ and a low negative correlation with $\mathrm{Pb}, \mathrm{Zn}$, $\mathrm{Cd}$ and $\mathrm{Sr}$ and a low positive correlation with $\mathrm{Cu}$. $\mathrm{Mn}$ showed a high positive correlation with $\mathrm{Co}$, and $\mathrm{V}, \mathrm{a}$ negative correlation with $\mathrm{Pb}, \mathrm{Zn}, \mathrm{Sr}$ and $\mathrm{Cd}$, and a low positive correlation with $\mathrm{Cu}, \mathrm{Ni}$, and $\mathrm{Cr}$.

$\mathrm{Cd}$ showed a high positive correlation with $\mathrm{Cu}$, $\mathrm{Pb}$ and $\mathrm{Zn}$, a negative correlation with $\mathrm{Ni}, \mathrm{Co}, \mathrm{Mn}, \mathrm{V}$, and $\mathrm{Cr}$, and a low positive correlation with $\mathrm{Sr}$. $\mathrm{Cr}$ showed a high positive correlation with $\mathrm{Ni}$, and $\mathrm{Co}$, a negative correlation with $\mathrm{Pb}$ and $\mathrm{Sr}$, and a low positive correlation with $\mathrm{Cu}, \mathrm{Zn}, \mathrm{Mn}$ and $\mathrm{V}$.

$\mathrm{Sr}$ showed a high positive correlation with $\mathrm{Zn}$, a negative correlation with $\mathrm{Ni}, \mathrm{Co}, \mathrm{Mn}$ and $\mathrm{V}$. V showed a high positive correlation with $\mathrm{Co}$ and $\mathrm{Mn}$, a negative correlation with $\mathrm{Pb}, \mathrm{Cd}$ and $\mathrm{Sr}$ and a low positive correlation with $\mathrm{Cu}, \mathrm{Zn}, \mathrm{Ni}$, and $\mathrm{Cr}$.

\subsection{Factor Analysis}

A varimax-rotation analysis was applied to the data set to separate between different components of the soil and the distribution of these components over the study area. The varimax-rotation analysis was also used to evaluate the possible sources of metals in this study. The metals were divided into three distinct factor groupings with Eigen values higher than one. Elemental loadings in these factors were given in Table 7 , and the factor loadings which are greater than 0.50 are significant in the interpretation of the data. Table 8 explained the total system variance of the metals in the soils.

Table 7: Factor Analysis showing the Rotated Component Matrix of the Study Area

\begin{tabular}{|l|l|l|l|}
\hline & Component & \multicolumn{2}{l|}{} \\
\hline & 1 & 2 & 3 \\
\hline $\mathrm{Cu}$ & .856 & .058 & .280 \\
$\mathrm{~Pb}$ & .676 & -.005 & -.469 \\
$\mathrm{Zn}$ & .961 & .092 & -.102 \\
$\mathrm{Ni}$ & .084 & .941 & .148 \\
$\mathrm{Co}$ & -.164 & .710 & .665 \\
$\mathrm{Mn}$ & -.248 & -.011 & .910 \\
$\mathrm{Cd}$ & .895 & -.145 & -.299 \\
$\mathrm{Cr}$ & .014 & .970 & .144 \\
$\mathrm{Sr}$ & .522 & -.520 & .188 \\
$\mathrm{~V}$ & .220 & .380 & .744 \\
\hline
\end{tabular}

Extraction Method: Principal Component Analysis.

Factor 1: $\mathrm{Cu}, \mathrm{Pb}, \mathrm{Zn}, \mathrm{Cd}$ and $\mathrm{Sr}$ (Felsic mineral-rich lithology, and anthropogenic influence)

Factor 2: $\mathrm{Ni}$, Co and $\mathrm{Cr}$ (Mafic mineral-rich lithology)

Factor 3: Co, Mn and V (Geochemical affinity and mafic mineral-rich lithology) 
Table 8: Total variance of metals in soils of the study area

\begin{tabular}{|c|c|c|c|c|c|c|c|c|c|}
\hline \multirow{2}{*}{ Component } & \multicolumn{3}{|c|}{ Initial Eigenvalues } & \multicolumn{3}{|c|}{$\begin{array}{l}\text { Extraction Sums of Squared } \\
\text { Loadings }\end{array}$} & \multicolumn{3}{|c|}{$\begin{array}{l}\text { Rotation Sums of Squared } \\
\text { Loadings }\end{array}$} \\
\hline & Total & $\begin{array}{l}\% \text { of } \\
\text { Variance }\end{array}$ & $\begin{array}{l}\text { Cumulativ } \\
\text { e \% }\end{array}$ & Total & $\begin{array}{l}\% \text { of } \\
\text { Variance }\end{array}$ & $\begin{array}{l}\text { Cumulativ } \\
\mathrm{e} \%\end{array}$ & Total & $\begin{array}{l}\% \text { of } \\
\text { Variance }\end{array}$ & $\begin{array}{l}\text { Cumulativ } \\
\mathrm{e} \%\end{array}$ \\
\hline 1 & $\begin{array}{l}3.93 \\
2\end{array}$ & 39.324 & 39.324 & 3.932 & 39.324 & 39.324 & 3.331 & 33.314 & 33.314 \\
\hline 2 & $\begin{array}{l}2.98 \\
5\end{array}$ & 29.851 & 69.174 & 2.985 & 29.851 & 69.174 & 2.777 & 27.773 & 61.088 \\
\hline 3 & 1.49 & 14.899 & 84.073 & 1.490 & 14.899 & 84.073 & 2.299 & 22.985 & 84.073 \\
\hline 4 & .875 & 8.753 & 92.826 & & & & & & \\
\hline 5 & .419 & 4.193 & 97.019 & & & & & & \\
\hline 6 & .168 & 1.684 & 98.703 & & & & & & \\
\hline 7 & .088 & .881 & 99.584 & & & & & & \\
\hline 8 & .029 & .294 & 99.878 & & & & & & \\
\hline 9 & .011 & 107 & 99.985 & & & & & & \\
\hline 10 & .002 & .015 & 100.000 & & & & & & \\
\hline
\end{tabular}

Extraction Method: Principal Component Analysis.

\section{Factor 1: $\mathrm{Cu}, \mathrm{Pb}, \mathrm{Zn}, \mathrm{Cd}$ and $\mathrm{Sr}$}

Factor 1 which explains $33.314 \%$ of the system variance (Table 8 ) has a high positive factor loading on $\mathrm{Cu}, \mathrm{Zn}$ and $\mathrm{Cd}$, and a moderate positive factor loading on $\mathrm{Pb}$ and $\mathrm{Sr}$. According to Goldschmidt's classification of elements, $\mathrm{Cu}, \mathrm{Pb}, \mathrm{Zn}$, and $\mathrm{Cd}$ are classified as chalcophile. However $\mathrm{Sr}$ is classified as a Lithophile.

$\mathrm{Cu}$ in the earth's crust is most abundant in mafic and intermediate rocks. It is considered among the mobile heavy metals inhypogenic processes and it is a very versatile trace cation which exhibits a great ability to chemically interact with mineral and organic components of soils. The concentrations of $\mathrm{Cu}$ in surface soils reflects the bioaccumulation of the metal as well as the anthropogenic sources (Kabata-Pendias and Pendias 2001). In the soils of the study area, Cu has a high positive correlation with both the anthropogenic and geogenic metals indicating that its contribution to the soils was from both geogenic and anthropogenic sources.

$\mathrm{Pb}$ has a high chalcopilic property. The natural content of $\mathrm{Pb}$ in soils is inherited from host rocks but most topsoils enriched in $\mathrm{Pb}$ are as a result of widespread pollution. $\mathrm{Zn}$ is distributed uniformly in magmatic rocks; however, the sources of $\mathrm{Zn}$ could be linked to emission and paints from vehicles, as well as wearing down of batteries. $\mathrm{Pb}$ and $\mathrm{Zn}$ showed a high positive correlation which indicates that their contribution to the soils of the study area was influenced partly by anthropogenic sources.

$\mathrm{Cd}$ is strongly associated with $\mathrm{Zn}$ in its geochemistry with the chemical composition of the rock as the main factor determining its content. $\mathrm{Sr}$ is a relatively common trace element in the earth's crust and it is likely to concentrate in intermediate magmatic rocks. The content of $\mathrm{Sr}$ is highly controlled by the parent rocks and climate.

\section{Factor 2: $\mathrm{Ni}, \mathrm{Co}$ and $\mathrm{Cr}$}

Factor 2 which explain $27.77 \%$ of the total system variance (Table 8 ), has a high positive factor loading on $\mathrm{Ni}$, Co and Cr. According to Goldschmidt's classification of elements, $\mathrm{Ni}$ and $\mathrm{Co}$ are classified as siderophiles but they can behave aschalcophiles and lithophiles in theearth crust while $\mathrm{Cr}$ is classified as lithophile

$\mathrm{Ni}$ is believed to be strongly associated with $\mathrm{Mn}$ and $\mathrm{Fe}$ oxides in most soils, less than 15 to $30 \%$ of the total $\mathrm{Ni}$ is extracted with the Mn oxides. In surface horizons, $\mathrm{Ni}$ appears to occur mainly in organically bound forms, a part of which may be easily soluble chelates. Anthropogenic sources of nickel include steel works, metal plating and coinage of body parts of vehicles, and fuel combustion.

The abundance of $\mathrm{Cr}$ indicates that they are mainly associated with ultramafic and mafic rocks. The $\mathrm{Cr}$ contents of soils are inherited from the parent materials and are therefore usually highly concentrated in soils derived from mafic rocks. Co has a high concentration in ultramafic rocks in the earth's crust. The concentration of Co in soils is inherited from parent materials. Soils over mafic rocks and soils derived from clay deposits contain the highest amounts of this metal. Co closely resembles $\mathrm{Mn}$ and $\mathrm{Fe}$, and its distribution in soils is strongly determined by $\mathrm{Mn}$ oxide phase formation.

\section{Factor 3: Co, Mn and V}

Factor 3 which accounts for $22.985 \%$ of the total system variance (Table 8 ), has a moderate positive factor loading on Co and a high positive factor loading on Mn and V. According to Goldschmidt's classification of elements, $\mathrm{Mn}$ and $\mathrm{V}$ are classified as lithophiles whereas Co can behave as both lithophile and siderophile on the earth's surface.

$\mathrm{V}$ is concentrated mainly in mafic rocks. The geochemical characteristics of $\mathrm{V}$ are strongly dependent on its oxidation state $(+2,+3,+4$ and +5$)$ and on the acidity of the media. $V$ is known to form various complexes of cationic and anionic oxides and hydroxyl oxides; therefore $\mathrm{V}$ displays various behaviours. 
$\mathrm{Mn}$ is one of the most abundant trace elements in the lithosphere. Their highest concentrations are usually associated with mafic rocks. In the soils of the study area, the association of $\mathrm{Co}$ and $\mathrm{V}$ in this factor is controlled by the geochemical affinity of the elements. $\mathrm{V}$ is identified to have preference for organic matter while Co has affinity for Fe-Mn phase (Pendias and PendiasKabata 2001). The association of elements in this factor is influenced by both mafic mineral-rich lithology and geochemical affinity. As shown by the geological map of Oyo town and environs mafic mineral-rich rocks in the area include biotite garnet schist, biotite schist, and biotite gneiss. These rock types are rich in mafic minerals such as biotite and hornblende.

\subsection{CONTAMINATION INDICES}

3.6. Geoaccumulation Index $\left(I_{\text {geo }}\right)$

Geoaccumulation indices were calculated using the average crustal abundance value for each metal as background value. The range of Geoaccumulation indices for the soils of the study area is presented in Table 9.

Table 9: Range of Geoaccumulation indices for soils of the study area

\begin{tabular}{|l|l|l|}
\hline Metals & Minimum & Maximum \\
\hline $\mathrm{Cu}$ & -3 & 1 \\
\hline $\mathrm{Pb}$ & 0 & 9 \\
\hline $\mathrm{Zn}$ & -1 & 3 \\
\hline $\mathrm{Ni}$ & -4 & 0 \\
\hline $\mathrm{Co}$ & -2 & 1 \\
\hline $\mathrm{Mn}$ & -1 & 0 \\
\hline $\mathrm{Cd}$ & -1.4 & -0.2 \\
\hline $\mathrm{Cr}$ & -3 & 3 \\
\hline $\mathrm{Sr}$ & -6 & -3 \\
\hline $\mathrm{V}$ & -2.8 & 0.1 \\
\hline
\end{tabular}

$\mathrm{Cu}$ ranged from -3 to 1 indicating a soil that is practically uncontaminated to moderately contaminated by $\mathrm{Cu}$ (Table 9 ). $\mathrm{Pb}$ ranged from 0 to 9 which showed that the soils were practically uncontaminated to extremely contaminated in $\mathrm{Pb}$ (Table 9). The high value of $\mathrm{Pb}$ could be linked to automobile emissions, wear and tear of tyres. $\mathrm{Zn}$ ranged from -1 to 3 which showed that the soil is practically uncontaminated to heavily contaminated by $\mathrm{Zn}$ (Table 9). The high value of $\mathrm{Zn}$ could be linked to lubricating oils in which it is added as an addictive. Ni ranged from -4 to 0 which showed that the soils are practically uncontaminated by Ni (Table 9). Co ranged from -2 to 1 showing that the soils are practically uncontaminated to moderately contaminated by $\mathrm{Co}$ (Table 9). The presence of $\mathrm{Co}$ could be linked to Lithium cobalt oxide $\left(\mathrm{LiCoO}_{2}\right)$ which is widely used in lithium ion battery as cathode. $\mathrm{Mn}$ ranged from -1 to 0 which showed that the soils are practically uncontaminated by $\mathrm{Mn}$ (Table 9 ). Cd ranged from -1.4 to -0.2 indicating that the soils are practically uncontaminated by $\mathrm{Cd}$ (Table 9 ). $\mathrm{Cr}$ ranged from -3 to 3 which showed that the soils are practically uncontaminated to heavily contaminated by $\mathrm{Cr}$ (Table 9). Sr ranged from -6 to -3 showing that the soils are practically uncontaminated by $\mathrm{Sr}$ (Table 9 ). $\mathrm{V}$ ranged from -2.8 to 0.1 which showed that the soils are practically uncontaminated to moderately contaminated by $\mathrm{V}$ (Table 9 ).

The percentage of metal in each class of geoaccumulation index and the percentage of metal contamination in the study area is as shown in Table 10 and Figure 4 respectively, while the range of geoaccumulation indices for each metal is shown in Figure 5. 
Table 10: Percentage of Metals in each class of Geoaccumulation Index for soils of the study area

\begin{tabular}{|c|c|c|c|c|c|c|c|c|c|c|c|c|}
\hline Class & Igeo Value & Soil Quality & $\begin{array}{l}\% \\
\mathrm{Cu}\end{array}$ & $\begin{array}{l}\% \\
\mathrm{~Pb}\end{array}$ & $\begin{array}{l}\% \\
\mathrm{Zn}\end{array}$ & $\begin{array}{l}\% \\
\mathrm{Ni}\end{array}$ & $\begin{array}{l}\% \\
\text { Co }\end{array}$ & $\begin{array}{l}\% \\
M n\end{array}$ & $\begin{array}{l}\% \\
\text { Cd }\end{array}$ & $\begin{array}{l}\% \\
\mathrm{~V}\end{array}$ & $\begin{array}{l}\% \\
\mathrm{Cr}\end{array}$ & $\begin{array}{l}\% \\
\mathrm{Sr}\end{array}$ \\
\hline 0 & Igeo $\leq 0$ & $\begin{array}{l}\text { Practically } \\
\text { Uncontaminated }\end{array}$ & 67 & 17 & 33 & 100 & 92 & 100 & 100 & 92 & 92 & 100 \\
\hline 1 & $0<$ lgeo $\leq 1$ & $\begin{array}{l}\text { Uncontaminated } \\
\text { to Moderately } \\
\text { Contaminated }\end{array}$ & 33 & 8 & 25 & - & 8 & - & - & 8 & - & - \\
\hline 2 & $1<$ lgeo $\leq 2$ & $\begin{array}{l}\text { Moderately } \\
\text { Contaminated }\end{array}$ & - & 17 & 25 & - & - & - & - & - & - & - \\
\hline 3 & $2<$ lgeo $\leq 3$ & $\begin{array}{l}\text { Moderate to } \\
\text { Heavily } \\
\text { Contaminated }\end{array}$ & - & 17 & 17 & - & - & - & - & - & 8 & - \\
\hline 4 & $3<$ lgeo $\leq 4$ & $\begin{array}{l}\text { Heavily } \\
\text { Contaminated }\end{array}$ & - & 17 & - & - & - & - & - & - & - & - \\
\hline 5 & $4<$ lgeo $\leq 5$ & $\begin{array}{l}\text { Heavily to } \\
\text { Extremely } \\
\text { Contaminated }\end{array}$ & - & 8 & - & - & - & - & - & - & - & - \\
\hline 6 & lgeo $>5$ & $\begin{array}{l}\text { Extremely } \\
\text { Contaminated }\end{array}$ & - & 16 & - & - & - & - & - & - & - & - \\
\hline
\end{tabular}

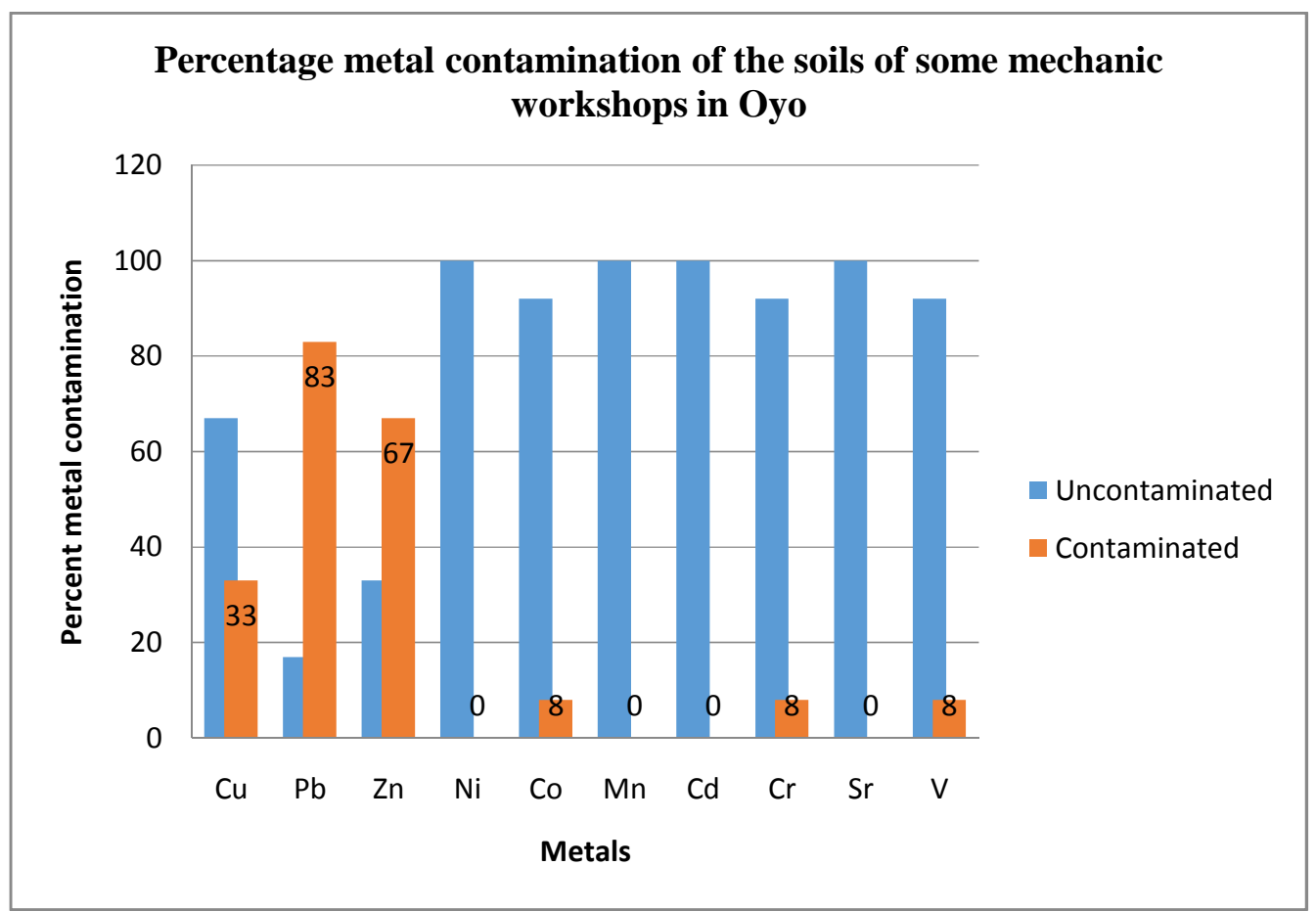

Figure 4: Percentage Metal contamination of the soils of some mechanic workshops in Oyo town 


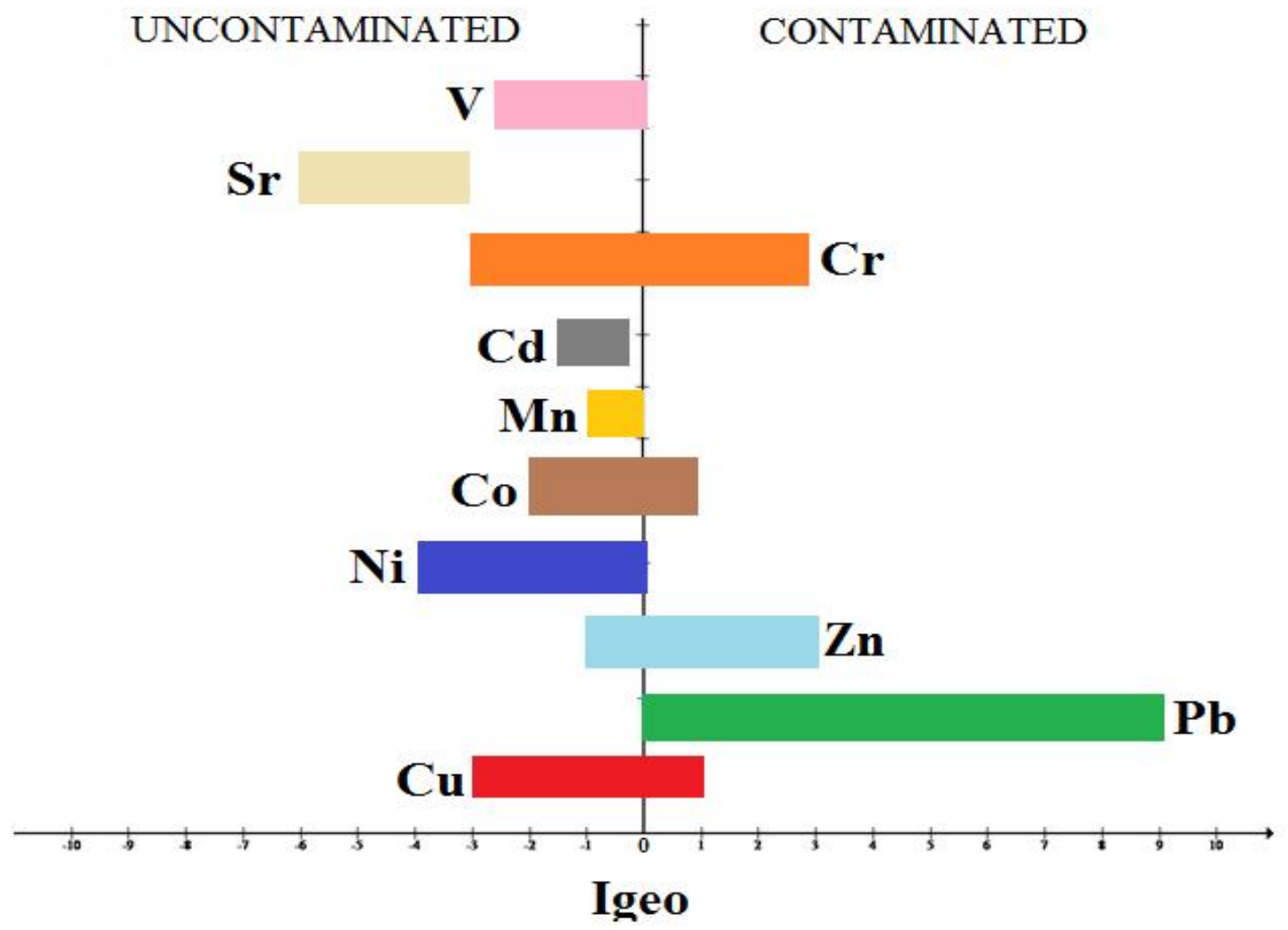

Figure 5: Geoaccumulation Index for soils in the study area 3.7 Contamination Factor and Degree of $\begin{aligned} & \text { study area as shown by the categories of contamination } \\ & \text { Contamination }\end{aligned}$
factor is presented in Table 11 and Figure 6. The measure of contamination in the soils of the

Table 11: Contamination Factors for Soils of some mechanic workshops in Oyo town

\begin{tabular}{|l|l|l|l|l|l|l|l|l|l|l|l|}
\hline Categories & Description & $\mathbf{C u}$ & $\mathbf{P b}$ & $\mathbf{Z n}$ & $\mathbf{N i}$ & $\mathbf{C o}$ & $\mathbf{M n}$ & $\mathbf{C d}$ & $\mathbf{C r}$ & $\mathbf{S r}$ & $\mathbf{V}$ \\
\hline $\mathrm{C}_{\mathrm{f}}^{\prime}<1$ & $\begin{array}{l}\text { Low } \\
\text { Contamination } \\
\text { Factor }\end{array}$ & & & & 0.36 & & & 0.75 & & 0.09 & 0.79 \\
\hline $1 \leq \mathrm{C}_{\mathrm{f}}^{\prime}<3$ & $\begin{array}{l}\text { Moderate } \\
\text { Contamination } \\
\text { Factor }\end{array}$ & 1.73 & & & & 1.38 & 1.16 & & 1.37 & \\
\hline $3 \leq \mathrm{C}_{\mathrm{f}}^{\prime}<6$ & $\begin{array}{l}\text { Considerable } \\
\text { Contamination } \\
\text { Factor }\end{array}$ & & & 4.38 & & & & & & & \\
\hline $\mathrm{C}_{\mathrm{f}}^{\prime} \geq 6$ & $\begin{array}{l}\text { Very high } \\
\text { Contamination } \\
\text { Factor }\end{array}$ & & 98.68 & & & & & & & & \\
\hline
\end{tabular}




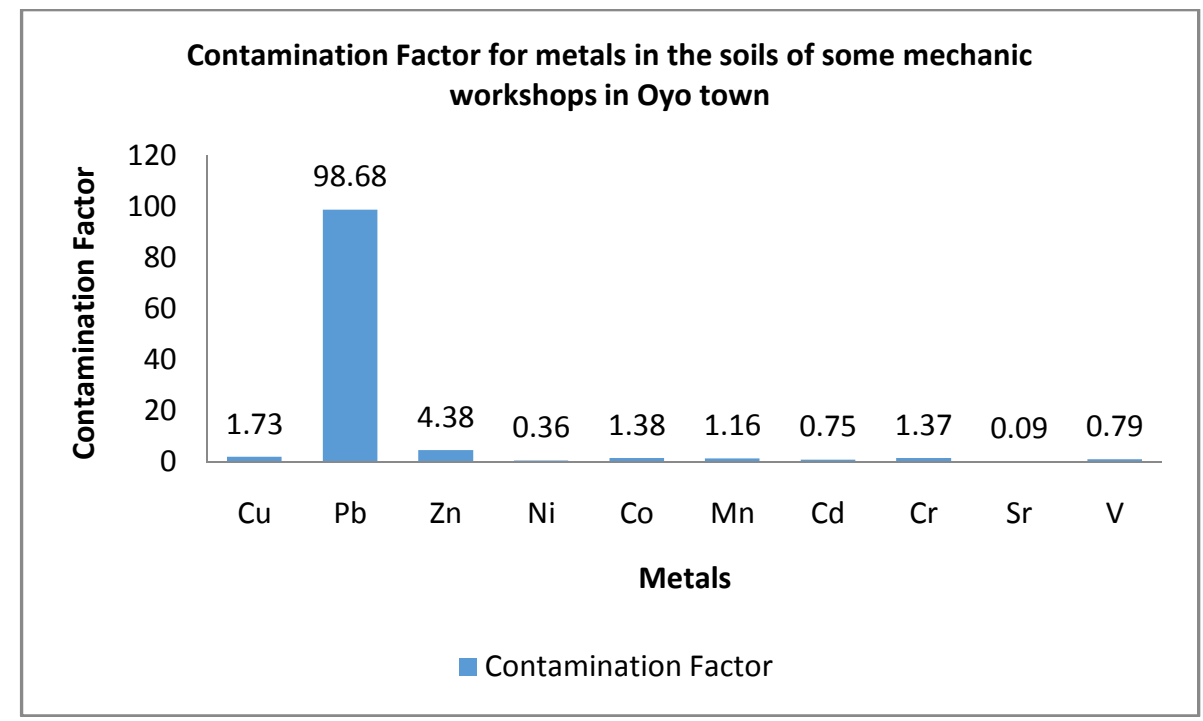

Figure 6: Contamination factor for metals in the soil of some mechanic workshops in Oyo town

$\mathrm{Ni}, \mathrm{Cd}, \mathrm{Sr}$ and $\mathrm{V}$ showed a low factor of contamination with values $0.36,0.75,0.09$ and 0.79 respectively. $\mathrm{Cu}, \mathrm{Co}, \mathrm{Mn}$ and $\mathrm{Cr}$ showed a moderate factor of contamination with values $1.73,1.38,1.16$ and 1.37. Zn showed a considerable factor of contamination with 4.38 while $\mathrm{Pb}$ showed a very high factor of contamination with 98.68 .
The degree of contamination which gives an assessment of the overall contamination of the soils has a value of 110.69 (Table 12) which indicates a very high degree of metal contamination due to the very high value for $\mathrm{Pb}$ contamination factor.

Table 12: Hakanson's Categories of Contamination degree

\begin{tabular}{llc}
\hline $\begin{array}{l}\text { Class of Contamination Soil Category } \\
\text { degree }\end{array}$ & $\begin{array}{l}\text { Degree of contamination } \\
\text { for the studied soils }\end{array}$ \\
\hline $\mathrm{C}_{\text {deg }}<8$ & Low degree of contamination & \\
$8 \leq \mathrm{C}_{\text {deg }} 16$ & Moderate degree of contamination & \\
$16 \leq \mathrm{C}_{\text {deg }} 32$ & Considerable degree of contamination & \\
$32 \leq \mathrm{C}_{\text {deg }}$ & Very high degree of contamination & 110.69 \\
\hline
\end{tabular}

\section{CONCLUSIONS}

The mean concentration of the metals in the soils around some automobile mechanic workshops in Oyo town as shown by this study was in the order $\mathrm{Pb}>\mathrm{Mn}>\mathrm{Zn}>\mathrm{Cr}>\mathrm{V}>\mathrm{Cu}>\mathrm{Sr}>\mathrm{Co}>\mathrm{Ni}>\mathrm{Cd}$. Factor analysis gave three factor groupings; Factor $1: \mathrm{Cu}, \mathrm{Pb}, \mathrm{Zn}, \mathrm{Cd}$ and $\mathrm{Sr}$ were mainly sourced from felsic mineral-rich lithologies and anthropogenic activities. Felsic minerals found in the rocks of Oyo town include plagioclase feldspars, microcline, quartz and muscovite. Factor 2: $\mathrm{Ni}, \mathrm{Co}$, and $\mathrm{Cr}$ were sourced mainly from mafic mineralrich lithologies. Mafic minerals found in the rocks around Oyo town include biotite, and hornblende. Factor 3: Co, $\mathrm{Mn}$, and $\mathrm{V}$ were sourced mainly from mafic mineral-rich lithologies and further influenced by geochemical affinity. Overall, the elemental association in the soils was influenced by lithology, geochemical affinity and anthropogenic activities such as indiscriminate disposal of domestic waste, and auto-mechanic workshop activities. Results of Geoaccumulation Index showed that the soils are practically uncontaminated by $\mathrm{Ni}, \mathrm{Mn}$,
$\mathrm{Cd}$ and $\mathrm{Sr}$, practically uncontaminated to moderately contaminated by $\mathrm{Cu}$, $\mathrm{Co}$ and $\mathrm{V}$, moderate to heavily contaminated by $\mathrm{Zn}$ and $\mathrm{Cr}$ and practically uncontaminated to extremely contaminated by $\mathrm{Pb}$. Also the soil showed considerable Contamination Factor for $\mathrm{Zn}$ and Very high contamination factor for $\mathrm{Pb}$. An overall assessment showed that the soils have very high degree of contamination value of 110.69 . This extreme value of degree of contamination portend a great danger to the health of plant, animal and man in these areas.

In view of the very high degree of soil contamination around auto-mechanic workshops in Oyo town, measures should be put in place to control further contamination of the environment. It is therefore pertinent that all mechanic workshops in this area be relocated to the outskirt of the town and a mechanic "villages" be established in carefully selected locations. Also, a more environmentally friendly method of waste disposal and management should be put in place, rather than the current practice of indiscriminate disposal of waste products from mechanic workshops. 


\section{REFERENCES}

Aelion, C. M., Davis, H. T., McDermott, S and Lawson,

A. B., 2009. Soil metal concentrations and toxicity: associations with distances to industrial facilities and implications for human health. Sci Total Environ, $\quad 407(7), \quad$ 2216-2223. http://dx.doi.org/10.1016/ j.scitotenv.2008.11.033.

Cai, J., Cao, Y., Tan, H., Wang, Y and Luo, J., 2011. Fractionation and ecological risk of metals in urban river sediments in Zhongshan City, Pearl River Delta. J Environ Monit 13:2450-2456.

Dada, S. S., 2006. Proterozoic Evolution of Nigeria. In Oshin. O, ed. The Basement Complex of Nigeria and its Mineral Resources (A Tribute to Prof. M. A. O. Rahaman). Akin Jinad and Co Ibadan, 29 44.

David, $O$ and Sunday, A., 2012. Assessment of vehicular pollution of road side soilsin Ota metropolis, Ogun State, Nigeria. Int J Civil Environ Eng 12, (4): 40-46.

Filani, M. O and Akintola, F. O., 1982. Ibadan Region, University of Ibadan, Ibadan.

Fraga, C. G., 2005. Relevance, essentiality and toxicity of trace elements in human health. Molecular Aspects of Medicine 26, (2005): 235-244.

Hakanson, L., 1980. An ecological risk index for aquatic pollution control: a sedimentological approach. Water Res., 14:975-1001.

Hani, A. and Kariminejad, M., 2010. "Toxic metal distribution in soils of KavehIndustrial city, Iran". World Applied Sciences Journal, 8, (11): 1333 1342.

Jaradat, Q., Masadeh, A., Zaitoun, M and Maitah, B., 2005. Heavy metal contamination of soil, plant and air of scrapyard of discarded vehicles at Zarqa City, Jordan. Soil Sediment Contam 14:449-462.

Jiang, M., Zeng, G., Zhang, C., Ma, X., Chen, M., Zhang, J., Lu, L., Yu, Q., Hu, L and Liu, L., 2013. Assessment of heavy metal contamination in the surrounding soils andsurface sediments in Xiawangang River, Qingshuitang District. PLoSOne 8, (8): e71176.

Johansson, S. A and Campbell, J. L., 1998. "PIXE: A novel technique for elements analysis", Campbell's first book on PIXE, John Wiley \& Sons, Inc. 1998.

Jones, H. A and Hockey, R. D., 196. The Geology of part of southwestern Nigeria. Geological Survey of Nigeria Bull, (31): 87.

Kabata-Pendias, A and Pendias, H., 2001. Trace elements in soils and plants. CRC Press Inc., Roca Baton, FI. Landrigan PJ (1994) Lead. In:
Rosenstock L, Cullen MR (eds) Textbook of clinical occupational and environmental medicine. Saunders, Philadelphia, 745-754.

Landrigan, P. J., 1994. Lead. In: Rosenstock L, Cullen MR (eds) Textbook of clinical occupational and environmental medicine. Saunders, Philadelphia, 745-754.

Loska, K., Wiechula, D and Korus, I., 2004. Metal contamination of Farming soils affected by industry. Environ. International, 30: 159-165.

Muller, G., 1969. Index of geoaccumulationin sediments of the Rhine River. Geo. J., 2, (3): 108-118 (11 pages).

Navarro, M., Pérez-Sirvent, C., Martínez-Sánchez, M., Vidal, J., Tovar, P and Bech, J., 2008. Abandoned mine sites as a source of contamination by heavy metals: a case study in a semi-arid zone. J Geochem Explor 96, (2-3): 183-193.

Nigeria Geological Survey Agency., 2008. Geological Map of Oyo and Environ.

OlanrewajuLawal, Samuel BankoleArokoyu and Innocent I. Udeh., 2015. Assessment of Automobile Workshops and Heavy Metal Pollution in a Typical Urban Environment in Sub-Saharan Africa. Environmental Research, Engineering and Management, 71, (1): 27-35.

Ololade, I. A., 2014. An Assessment of Heavy-Metal Contamination in Soils within Auto-Mechanic Workshops Using Enrichment and Contamination Factors with Geoaccumulation Indexes. Journal of Environmental Protection, 5, 970-982.

Rahaman, M. A., 1976. Review of the basement geology of south-western Nigeria. In: Geology of Nigeria, Kogbe, C.A. (ed.), Elizabethan Press: Lagos. P41-58.

Syed, R. R., Dilara, K., Tanveer, M. A., Mohammad, S. I., Mohammad, A. A and Mohammad, A. A., 2012. Assessment of heavy metal contamination of agricultural soil around Dhaka export processing zone (DEPZ), Bangladesh: implication of Seasonal Variation and Indices. Appl Sci 2:584601.

Tamene, F., 2008. Assessment of lead toxicity awareness among battery charging garage and workshop workers and levels of lead in piped drinking water of Addis Ababa, Ethiopia (Doctoral dissertation, aau).

Vaalgamaa, S and Conley, D., 2008. Detecting environmental change in estuaries: nutrient and heavy metal distributions in sediment cores in estuaries from the Gulf of Finland, Baltic Sea. Estuar Coast Shelf Sci 76, (1): 45-56. 


\section{APPENDIX}

Statistical summary of elemental concentrations in the soils

\begin{tabular}{|c|c|c|c|c|c|c|}
\hline & $\mathrm{N}$ & Minimum & Maximum & Sum & Mean & $\begin{array}{l}\text { Std. } \\
\text { Deviation }\end{array}$ \\
\hline $\mathrm{Cu}$ & 12 & 13.00 & 169.00 & 1036.00 & 86.33 & 52.78 \\
\hline $\mathrm{Pb}$ & 12 & 14.00 & 10000.00 & 14802.00 & 1233.50 & 2883.70 \\
\hline $\mathrm{Zn}$ & 12 & 45.00 & 745.00 & 3680.00 & 306.67 & 228.51 \\
\hline $\mathrm{Ni}$ & 12 & 6.00 & 132.00 & 323.00 & 26.92 & 33.51 \\
\hline Co & 12 & 10.00 & 66.00 & 365.00 & 30.42 & 15.60 \\
\hline $\mathrm{Mn}$ & 12 & 584.00 & 1831.00 & 13888.00 & 1157.33 & 407.39 \\
\hline $\mathrm{Cd}$ & 12 & 0.40 & 0.90 & 6.30 & 0.53 & 0.21 \\
\hline $\mathrm{Cr}$ & 12 & 25.00 & 902.00 & 1645.00 & 137.08 & 242.66 \\
\hline Sr & 12 & 9.00 & 89.00 & 421.00 & 35.08 & 24.47 \\
\hline V & 12 & 24.00 & 173.00 & 1041.00 & 86.75 & 40.08 \\
\hline $\begin{array}{l}\text { Valid } N \\
\text { (listwise) }\end{array}$ & 12 & & & & & \\
\hline
\end{tabular}

